\title{
FOOD MARKETING TO CHILDREN - REVIEW OF THE ISSUE FOR FURTHER EXPLORATION
}

\author{
Olšanová, $\mathbf{K}$.
}

This paper provides an overview of key stakeholders involved in food marketing to children in Europe and in the Czech Republic. It analyzes the role of the legislation as well as voluntary codes of conduct in the food industry. The industry part of the issue is also covered by an explanation of their role and position in the obesity issue. The form of food industry cooperation in the Food Chamber through a working group of involved companies is analyzed and an example of a corporate responsibility program is shown. The paper serves as a review of the issue for further exploration needs.

JEL classification: M31, M37, M38

Keywords: Advertising to children; self-regulation; ethics; food industry.

\section{Introduction}

Marketing ethics has been discussed since the beginning of the 1990s. From mainly academic discussions (Leigh \& Murphy, 1999), the issue has received the attention of many industries. Many businesses responded to the discussion by adopting new ways of operating their businesses, which later developed into voluntary codes of conduct. Advertising can be seen as one of the factors that contribute to shaping people's view of life, and the basic values, attitudes and cultural ideas that are dominant in society (Grundey, 2007, p. 60). Currently there are many issues discussed under the theme of marketing ethics. Namely these are (Grundey, 2007, p. 42):

- Product safety and liability,

- advertising truthfulness and honesty,

- fairness in pricing,

- power within the channels of distribution,

- privacy in internet and database marketing, and

- forthrightness in selling.

There is a link between the ethical issues in marketing to children and advertising truthfulness and honesty. This paper will focus on explaining key milestones of the regulation's development, roles of key stakeholders and then analyze the issues recently regulated in the voluntary code of advertising in the Czech Republic.

\section{Definition of a Child and Marketing to Children}

In regulations, children are variously described as "minors", "juveniles", "young people" or "children" (Grundey, 2007). In EU Member States, a minor is defined as a person under 18 years of age, with the exception of Austria, where the upper age limit is 19 years. The United Nations Convention on the Rights of the Child defines children as persons aged 18 years and under. When specified in national broadcast legislation, the definition of a "child" typically ranges from under 12 years of age to under 16 years (Table 1 ).

Table 1: Examples of the "age of a child" as defined in national broadcast legislation

\begin{tabular}{|l|c|}
\hline \multicolumn{1}{|c|}{ Country } & Age (less than, in years) \\
\hline Australia & 14 \\
\hline Canada & 12 \\
\hline Quebec & 13 \\
\hline China, Hong Kong & 15 \\
\hline Fiji & 15 \\
\hline Finland & 12 \\
\hline Germany & 14 \\
\hline The Netherlands & 12 \\
\hline Norway & 12 \\
\hline Republic of Korea & 13 \\
\hline Sweden & 12 \\
\hline United Kingdom & 16 \\
\hline
\end{tabular}

Source: Hawkes (2004). 
In the Czech Republic, the "Advertising Regulation Act" gives special conditions to advertising to persons younger than 18 years old. Therefore this age is the benchmark for advertising targeted to children in the context of this article. Making the assessment whether the campaign is or is not actually directed to children is neither straightforward nor easy. A TV ad, for example, could be directed at parents rather than at children, or could be targeted at teenagers but viewed by the under-12s. Most regulations do not specify criteria for defining "child-directed" marketing (Grundey, 2007).

\section{Key Stakeholders in Regulation of Advertising to Children}

United Nations: Convention on the Rights of the Child

In 1989 the United Nations Assembly adopted the Convention on the Rights of the Child (CRC), which has become the most widely accepted human rights treaty ever (UN, 2013). It has been ratified in 193 countries. Under the Convention, every child is recognized as a subject of rights, with the right to special protection. Equal and inalienable human rights are to be enjoyed by all children regardless of where born or to whom born, regardless of sex, religion or social origin. Article 17 deals with the media, Article 12 recognizes the right of the children to express their own views on matters affecting them and Article 13 enhances the freedom to express itself.

\section{European Union: Development of the Audiovisual Regulatory Framework}

The first attempts to shape a European Union audiovisual policy were triggered by the developments of satellite broadcasting in the early 1980s. Since the adoption of the Television without Frontiers Directive (TVwF) in 1989, technological and market developments have made it necessary to amend the audiovisual regulatory framework. When the Directive was first adopted there was no need to discuss how food advertising should be regulated on the European level. As a result of rising levels of obesity in all EU member states, the approach has changed. The Directive was revised in 1997 and 2007. With the last revision, the Directive was renamed Audiovisual Media Services Directive (AVMSD) and then codified in 2010 (The Audiovisual Media Services Directives - AVMSD). The Directive covers both traditional television broadcasting and new, on-demand services like on-demand films and news. These two are distinguished based on who decides when a specific program is aired and whether the airing schedule exists. The "linear" services are those following a schedule prepared by a broadcaster and "non-linear" or on-demand services leave users to decide when they want to watch the program. The Directive also extends to all audiovisual media the country of origin principle, meaning that the rules of the country in which the broadcasting provider is located are the decisive factor. The providers can easily identify the rules applicable to them on a straightforward basis.

For the first time, the directive addresses the issue of "fatty foods" in the commercials aired during children's programs. The goals of the EU coordination are defined as:

- Providing rules to shape technological developments,

- creating a level playing field for emerging audiovisual media,

- preserving cultural diversity,

- protecting children and consumers,

- safeguarding media pluralism,

- combating racial and religious hatred,

- guaranteeing the independence of national media regulators.

Article 9 (2) sets rules for the advertising of "unhealthy" food and drinks in children's programs by quoting that governments and the Commission must encourage media service providers to develop codes of conduct curtailing such advertising. The codes of conducts are forced by the Directive in different fields, under the umbrella of "Self-regulation, combined with government regulation" (Article 4 (7)). The new rules require governments to encourage self-regulation in certain fields, sometimes combined with government intervention ("co-regulation") - where their legal systems allow. Such regimes must be broadly accepted by the main stakeholders and provide for effective enforcement.

\section{EASA - European Advertising Standards Alliance}

The European Advertising Standards Alliance (EASA) is a non-profit organization based in Brussels. Its main goals are to:

- Consolidate the advertising self-regulation in Europe,

- help European countries create self-regulatory bodies and legal framework,

- promote self-regulation in advertising as a more flexible alternative to detailed legislation,

- coordinate cross-border complaints with the aim of fast resolution.

EASA members sign the Advertising Self-Regulation Charter (the EASA Charter). Doing so, they should comply with the fundamental principles of the Charter, namely: (i) the nation's self-regulation should compre- 
hensively cover all forms of advertising and all advertisers, (ii) they issue a code of ethics and will independently deal with complaints through a competent authority, (iii) the whole procedure will mean no costs for the consumer, etc.

EASA publishes a Blue Book informing advertisers, the media, advertising agencies and other stakeholders about the level of self-regulation in member states. Additionally, it provides its audience with useful guidelines on how to create communications in accordance with these rules, as well as with a detailed description of EU legislation with respect to advertising regulation and their comparison with individual modifications within the legislation of member states (EASA ALLIANCE, 2013).

\section{Self-regulatory Rules}

Self-regulation in the advertising sector is the recognition that the advertising industry (advertisers, agencies and the media) creates advertising that complies with a set of ethical rules. According to which, the advertising should be legal, decent, honest, truthful, prepared with a sense of social responsibility to the consumer as well as society as a whole and created with due respect to the rules of fair competition (EASA ALLIANCE, 2013). The ethical rules are usually in the form of a code based on the original ICC codes, meaning the Codes of Marketing and Advertising Practices, originally drawn up by the International Chamber of Commerce (ICC) in 1937, which inspired many of the national self-regulatory codes currently in use. Self-regulation exists in most European countries.

There are two ways to ensure that advertising complies with the ethical rules: (i) detailed legislation or (ii) self-regulation. It is now widely accepted that self-regulation works best within a legislative framework. The law lays down broad principles, e.g. that advertising should not be misleading, while self-regulatory codes, because of their greater flexibility, can deal efficiently with the details of individual advertisements.

\section{Regulation in the Czech Republic}

\section{Self-regulation}

ACzech self-regulation initiative (Rada pro reklamu, RPR) was founded in 1994 by the representatives of advertisers, advertising agencies and media and since the beginning, it has been a member of the European Advertising Standards Alliance (EASA). The Code of Advertising Practice was agreed upon and adopted by the General Assembly on November 2, 1994. Divided into two parts, general and special, the Code contains general and particular rules of advertising. The latest version of the Code was adopted at the General Assembly meeting in May 2007.

RPR consists of the General Assembly (covering all members), the Arbitration Committee, the Executive Committee, Supervisory Board and the Secretariat. Representatives of the founders, e.g. advertising agencies, advertisers and the media, are members of the Executive Committee which deals with issues between the sessions of the General Assembly. In 2013, the food industry is directly represented by companies Danone, Ferrero, Nestlé and a subsidy of McDonalds. Indirectly, most of the food producers (both local and international) are represented through the Food Chamber (Potravinářská komora, PK) and the Czech Association of Branded Goods Producers (Český svaz značkových výrobců, ČSZV) (Rada pro reklamu, 2013).

The Arbitration Committee has the exclusive right to make decisions regarding complaints received by the RPR. The Committee also reviews submitted materials and recommendations made by the Secretariat. The Arbitration Committee has 13 members, including currently two lawyers, two representatives of advertising agencies, two advertisers, four members from the Czech media, as well as a psychologist and a sexologist. The committee has regular monthly meetings chaired by the President of the RPR. The remaining bodies of the RPR are focused on administration (The Supervisory Body - finance and operations, Secretariat - regular administration).

\section{RPR's Scope of Work}

RPR's main role is the assessment of complaints regarding advertising in press, outdoor, direct mail, audio-visual production, radio and $\mathrm{TV}$, cinema and the Internet. The complaints with prevailing legal issues are out of its scope as it focuses primarily on ethics. The Arbitration Committee is authorized to initiate an assessment process based on a complaint received from any public or private body in the Czech Republic. RPR can also act based on its own initiative once they realize that particular ad may violate certain provisions of the Code of Advertising.

The Arbitration Committee is not allowed to impose any financial penalties or any other sanctions. The outcome of the process has a form of decision serving as recommendation to the advertiser. If they find out that the advertiser does not follow the recommendation, they may initiate a suggestion to the Regional Trade Licensing Office (Krajský živnostenský úřad, KŽÚ), which has the legal power to penalize the advertisers.

Besides the main role of assessing the advertising with respect to the Code, the organization performs the following activities: 
- Publishes the Code of Advertising,

- educates the advertisers and other stakeholders regarding the ethical and self-regulation issues,

- copy advice,

- issues expert advices and suggestions to KŽÚs,

- protects the interests of the advertising industry and contributes to the initialization, drafting and approvals of legislation affecting advertising and marketing communications, and

- represents its members in EASA - The European Advertising Standards Alliance.

\section{Complaints Statistics with Focus on Food Industry}

The Code applies the same rules for advertising of food and drinks as for any other product ads. Advertising should not give the impression of a need to purchase food or beverages or encourage children to persuade others to buy them. In no case should it question the role of parents or other persons who are positive models for children regarding proper nutrition. The number of complaints received by RPR within the period 2002 to May 2013 is summarized in Figure 1. Referring to Table 2, none of the complaints accepted by the RPR were reasoned by the advertising to children part of the Code.

The most known issue in terms of advertising to children in the Czech Republic was a TV spot for the confectionery brand Fidorka, produced by Opavia-LU (later part of an acquisition of Kraft Foods). A girl younger than 10, looking like an angel, does not hesitate to throw a plastic doll against the car bonnet to get her favorite chocolate delicacy. The advertisement raised a wave of public attention and television stations were penalized by The Radio and Television Broadcast-

Table 2: The food brands' complaints with a positive decision of the RPR (e.g. defective according to the Code of Advertising)

\begin{tabular}{|c|c|c|c|c|}
\hline $\begin{array}{l}\text { Year of } \\
\text { complaint }\end{array}$ & Complainant & Brand/Brand Owner/media & $\begin{array}{l}\text { Issue description } \\
\quad \text { (if available) }\end{array}$ & Reasoning \\
\hline 2004 & Alphaduct & $\begin{array}{l}\text { Karlovarské minerální vody/Magnesia/ } \\
\text { print }\end{array}$ & $\begin{array}{l}\text { Claiming more } \\
\text { magnesium }\end{array}$ & Consumer protection \\
\hline 2005 & $\begin{array}{l}\text { Private person } \\
\text { RPR's monitoring } \\
\text { Private person } \\
\text { Private person }\end{array}$ & $\begin{array}{l}\text { Carrefour/Výprodej století (The sale of } \\
\text { the century)/leaflets } \\
\text { Alphaduct/Korunní mineral water/TV ad } \\
\text { Pepsi Co/Pepsi/cinema ad } \\
\text { Tesco Stores/grilled chicken at } 59.90 \\
\text { Czk/print }\end{array}$ & $\begin{array}{l}\text { Sweet childhood } \\
\text { Kung-fu/ violence }\end{array}$ & $\begin{array}{l}\text { Comparative, } \\
\text { misleading, deceptive } \\
\text { Consumer protection } \\
\text { Violence } \\
\text { Comparative, } \\
\text { misleading, deceptive }\end{array}$ \\
\hline 2006 & $\begin{array}{l}\text { Private person and } \\
\text { ČSZV (Branded } \\
\text { goods producers } \\
\text { association }\end{array}$ & Plus Discount/Rama vs. Rela/leaflets & $\begin{array}{l}\text { Confusing brands - } \\
\text { Rama vs. Rela at Plus } \\
\text { Discount }\end{array}$ & $\begin{array}{l}\text { Comparative, } \\
\text { misleading, deceptive }\end{array}$ \\
\hline 2007 & Private person & Zott s.r.o./Jogobella yoghurts/TV ad & & $\begin{array}{l}\text { Comparative, } \\
\text { misleading, deceptive }\end{array}$ \\
\hline 2008 & $\begin{array}{l}\text { RPR's monitoring } \\
\text { Private person } \\
\text { Private person }\end{array}$ & $\begin{array}{l}\text { TECFOOD s.r.o./Kamikaze/ Billboards } \\
\text { IDC/Mila brand/TV ad } \\
\text { Walmark/SlimCup/TV ad }\end{array}$ & & $\begin{array}{l}\text { Protection of personality } \\
\text { Comparative, } \\
\text { misleading, deceptive } \\
\text { Consumer protection }\end{array}$ \\
\hline 2009 & Private person & NetMilk/milk products/billboards & Sexist advertising & Consumer protection \\
\hline 2010 & $\begin{array}{l}\text { Czech beer and } \\
\text { malt association }\end{array}$ & Pivovar Rohovec/Skalák brand/labels & Sexist advertising & Consumer protection \\
\hline 2011 & Private person & Kofola/extra bylinková/TV advertising & $\begin{array}{l}\text { Student and teacher } \\
\text { relation }\end{array}$ & Consumer protection \\
\hline 2012 & Private person & $\begin{array}{l}\text { Bernard brewery/ } \\
\text { Bernard/billboards }\end{array}$ & Plastic women & Sexist \\
\hline 2013* & Private person & $\begin{array}{l}\text { Bernard brewery/ } \\
\text { Bernard/billboards }\end{array}$ & Amnesty & Protection of personality \\
\hline
\end{tabular}

Source: Author based on RPR data (Rada pro reklamu, 2013). 
Figure 1: The total amount of complaints received by RPR 2002 $-2013^{*}$
Source: Author based on data provided by RPR (Rada pro reklamu, 2013).

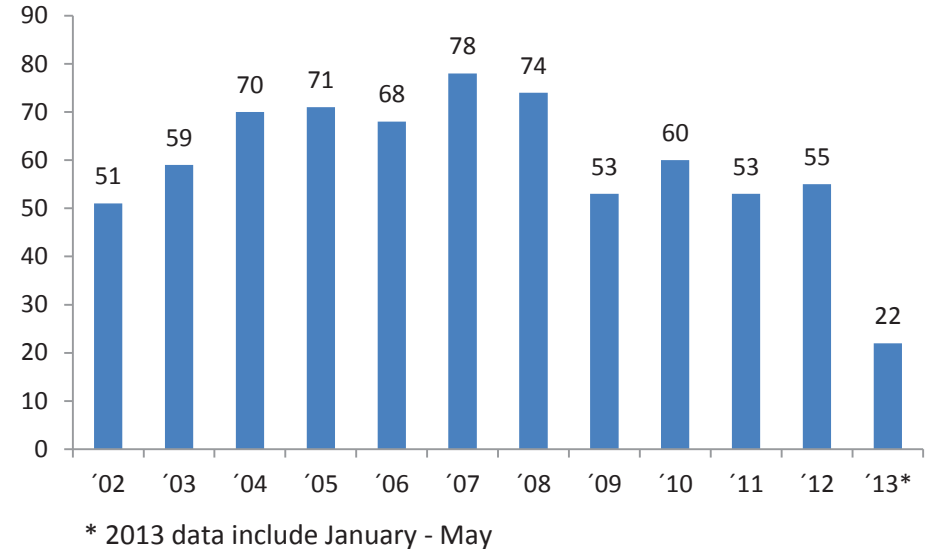

ing Council. One of the TV stations, Prima, appealed but the Supreme Administrative Court decided that the video could hurt the mental or moral development of children and forced the TV station to pay. The RPR found the spot not defective as it was within the limits of advertising exaggeration. The Council, nevertheless, recommended airing the spot after 22:00 when it could potentially be viewed by children able understand the advertising hyperbole.

\section{The Legal Framework of Advertising to Children in the Czech Republic}

As stated above, self-regulation is based on voluntary industry initiative. The formal legislation gives more formal borders for both advertisers and the media. In the Czech Republic, Law No. 40/1995 Coll., "The regulation of advertising" (Sbírka zákonů ČR, 2013), as amended (the "Advertising Regulation Act"), com- prehensively regulates the issue of advertising. It pro- hibits the advertising of goods or services that are contrary to the laws of the Republic; advertising based on subliminal perception, deceptive advertising, hidden advertising, distribution of unsolicited advertising (harassing the recipient or leading to his expenditures) and the advertising that is contrary to good morals. The act also prohibits advertising directed at the audience under 18 years of age, which encourages behavior prejudicial to their health, mental or moral development, advertising of tobacco and alcohol products, as well as sponsorship of sporting events by tobacco manufacturers and reduces the spread of advertising on firearms and ammunition.

The rules for protection of children and juveniles are set in $\S 2 \mathrm{c}$. With respect to persons under 18 years old, advertising shall not:

- Encourage behavior prejudicial to their health, mental or moral development,
- recommend to purchase products or services by exploiting their inexperience or credulity,

- encourage them to persuade their parents or legal guardians or others to purchase the goods or services,

- utilize the special confidence they have to their parents or legal guardians or other persons in an inappropriate manner showing them in dangerous situations.

\section{Relation between Self-regulation and the Legal Framework in the Czech Republic}

With the adoption of Act no. 40/95, the RPR (in addition to its core business, which is evaluating the acceptability of ads from the ethical point of view) has become the institution from which the supervisory authorities in charge of compliance with the mentioned law (regional trade licensing offices, the Council of the Czech Republic for Radio and Television Broadcasting, Ministry of Health, etc.) require expert advice on the application of the above law in practice. In this context, the Council issued more than 250 expert pieces of advice on compliance with the advertising law to regulate advertising for regional trade offices of the Czech Republic (Rada pro reklamu, 2013).

\section{The Development of the Obesity Issue and its Key Stakeholders}

\section{World Health Organization}

Obesity has been discussed as a major concern since the World Health Organization published its Report of the Director General in 1998: "Life in the 21st century. A vision for all" emphasizing that "Obesity is increasing, especially in the younger age group. Nutritional problems, especially overconsumption of fats or sugars, are taking their toll." (World Health Organization, Geneva, 1998 , p. 88). Nowadays, according to WHO, being overweight and obese is the fifth leading risk for global 
Figure 2: Prevalence of being overweight and obese $\left(B M I \geq 25 \mathrm{~kg} / \mathrm{m}^{2}\right)$ in the Czech Republic, 2008

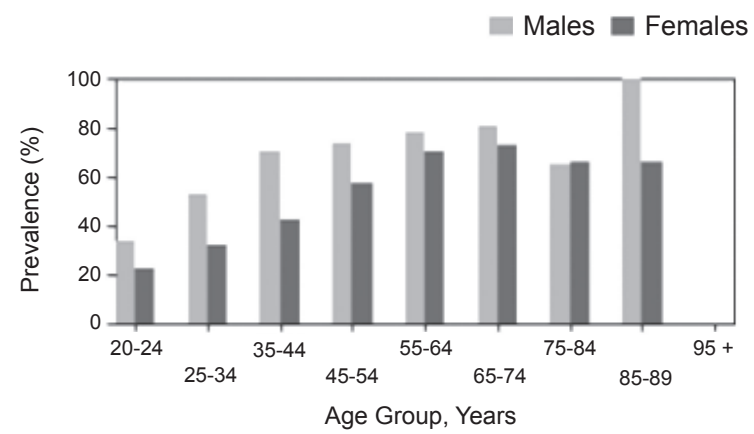

Source: (World Health Organization, 2013).

Figure 3: Prevalence of the obesity $\left(B M I \geq 30 \mathrm{~kg} / \mathrm{m}^{2}\right)$ in the Czech Republic, 2008

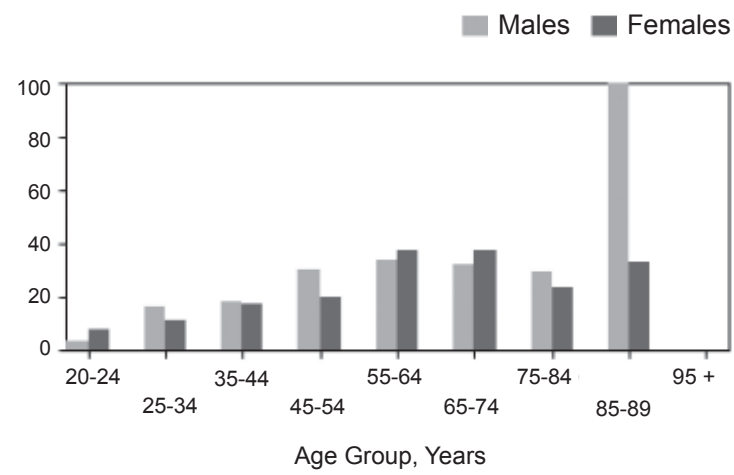

Source: (World Health Organization, 2013).

deaths. More than 40 million children under the age of five were overweight in 2011 and the issue is growing in low- and middle-income countries, particularly in urban settings. More than 30 million overweight children are living in developing countries and 10 million in developed countries (World Health Organization, 2013).

In the Czech Republic, the most relevant policy document is the "National Action Plan against Obesity" promulgated by the Ministry of Health and endorsed in 2007, which is based on the WHO Global Strategy on Diet, Physical Activity and Health. But the plan has never come into action. In 2004, the Minister of Health established the National Council for Obesity as a permanent specialist advisory body to the Ministry of Health. The basic task of the Council is the implementation of the National Action Plan against Obesity. The Council has not met since autumn 2007 (IOTF, 2013). In order to demonstrate the obesity issue in the Czech Republic, Figure 2 and 3 show the prevalence of being overweight and obese as published by the World Health Organization. The data for children are available from a different source and will be mentioned at a later stage.

WHO specifies why obesity during childhood creates risk for future adults. An increased $\mathrm{BMI}^{1}$ increases the risk of diseases such as cardiovascular diseases (mainly heart disease and stroke), diabetes, musculoskeletal disorders (osteoarthritis) and some cancers (endometrial, breast, and colon). The obesity of children is, according to $\mathrm{WHO}$, associated with a higher chance of obesity, premature death and disability in adulthood. Additionally, the obese children experience breathing difficulties, increased risk of fractures, hypertension, early markers of cardiovascular disease, insulin resistance and psychological effects (World Health Organization, 2013).

\section{IOTF (International Obesity Taskforce)}

The U.K. based IOTF (The International Obesity Task Force) was originally convened in 1995 by Professor Philip James to prepare the first scientific research report on the global epidemic of obesity, which served as a working draft for the first WHO expert consultation on obesity held in Geneva in 1997. The report established the criteria for assessing obesity, and was distributed to all health ministers at the World Health Assembly in 1998.

The most important milestones in the history of the taskforce are:

- "Preventing Childhood Obesity" - published in June 2005 in cooperation with The British Medical Association, focused on recommendations for school and community programs. The document notes the need to address inequalities and the pervasive influence of marketing on children's food choices.

- Drafting the "Sydney Principles" (in May 2006), following the WHO forum and consultation on marketing to children in Oslo, which is a set of rightsbased principles to protect children against exposure to commercial promotions of obesogenic foods and beverages.

- A draft code, "Recommendations for an International Code on Marketing of Foods and Non-Alcoholic Beverages to Children" developed in cooperation with "Consumers International" in 2008.

$1 \quad$ BMI = Body Mass Index, the measurement commonly used to classify overweight and obesity in adults, defined as a person's weight in kilograms divided by the square of his height in meters $\left(\mathrm{kg} / \mathrm{m}^{2}\right)$. The WHO definition is: BMI $\geq 25$ overweight, $\mathrm{BMI} \geq 30$ obesity 
The IOTF provides highlights of the obesity figures in many countries; the research conducted in 2008 shows the obesity figures for adults in the Czech Republic: 42.8 percent of men (aged 20+) were overweight, 23.9 percent of men (aged 20+) were obese, 29.2 percent of women (aged 20+) were overweight and 22.3 percent of women (aged 20+) were obese. The data for children are based on a 2005 survey and are as follows: 18.6 percent of boys (aged 6-17) were overweight, 6 percent of boys (aged 6-17) were obese; 12.1 percent of girls (aged 6-17) were overweight and 4.8 percent of girls (aged 6-17) were obese (IOTF, 2013).

\section{The Food Industry}

Apart from the individual responsibilities of everyone for his/her own health in terms of balanced energy intake and relevant physical activity, WHO has a strong standpoint regarding the behavior of other societal stakeholders because individual responsibility can have its effect only where people have access to a healthy lifestyle. This means not only the obvious public and private stakeholders but also the food industry. Their contribution to promoting of healthy diets was defined as:

- Reducing the fat, sugar and salt contents of processed foods,

- ensuring that healthy and nutritious choices are available and affordable to all consumers,

- practicing responsible marketing especially that which is aimed at children and teenagers, and

- ensuring the availability of healthy food choices and supporting regular physical activity practice in the workplace (World Health Organization, 2013).

Food industry leaders are proving their responsibility in terms of ethical advertising to children and with respect to the growing obesity trends by their active presence in the institutions dealing with these issues. The Food Chamber (Potravinářská komora, PK) is the institution with the highest coverage of food producers in the Czech Republic. One of their working groups is formed mainly by international food producers (with the exception of Kofola and Agrofert): Unilever, Mars, Mondelez Czech Republic, Ferrero, Hamé, Nestlé, Coca-Cola and United Bakeries (Potravinářská komora, 2013). The working group, as part of this large association, meets regularly for discussions regarding the latest development of EU legislation and self-regulation. One of the outcomes of their work is enrichment of the self-regulating code (RPR) via articles regarding responsible advertising of food related to children (Chapter 2 of the code related to food and soft drinks advertising).
Consensus of the food industry regarding the importance of a balanced lifestyle is highlighted in the sub-page of the Food Chamber called "Healthy lifestyle - balance between nutrition and physical activity" (Foodnet, 2013). Broadly acceptable references and tips are provided there and respected nutritionists and researchers in terms of obesity and healthy diets are communicated. The food brands that might be potentially threatened by tighter food legislation in terms of food labeling, portion sizes, advertising and targeting are proactively seeking opportunities to prove that obesity has always two sides, e.g. the energy in-take and output in the form of physical activity. This is the main reason why the companies support many sports as well as balanced lifestyle activities. One of the best examples is McDonald's Cup, based in 2002 as a football competition targeted to primary schools in the Czech Republic. The statistics for 2011/12 school year shows participation of 3,196 schools across all regions of the Czech Republic and the number is increasing each year since the launch of this activity (McDonald's Cup, 2013).

\section{Conclusion}

The paper presents an introduction to the ethical issues regarding marketing to children. It defines the child and marketing to children from the European perspective with a deeper focus on the Czech Republic. In terms of regulation of advertising to children, it analyzes the key stakeholders and their approach to the issue from both a legislative and self-regulation perspective. Self-regulation in the Czech Republic is introduced from the perspective of the self-regulation initiative (Rada pro reklamu) as well as from the food industry, including an example of a responsible approach to the obesity issue of one of the industry representatives.

The analysis of complaints makes it evident that the food industry in the Czech Republic behaves in-line with the self-regulation in terms of both advertising to children and a responsible approach to obesity issues. The food producers, on the contrary, promote a balanced approach to a healthy lifestyle through many activities either independently (McDonald's Cup presented as an example) or through associations. The example of the Food Chamber and its working group focused on a healthy lifestyle was discussed.

Legislation, self-regulation and pressure from different organization focused on obesity issue put the producers under pressure in terms of new product development targeted to children. Many regulatory aspects have to be considered within the whole inno- 
vation tunnel: from the $R \& D$ stage through product concepts to targeting, communication and point of sales. Food innovations targeted to children have to deal sensitively with those limitations with respect to the fact that regulation can only get stricter in the future. A responsible food industry approach aims to enhance self-regulation at the expense of strict regulations known from the tobacco industry as the worst scenario for the producers.

\section{References}

AVMSD (2013). The Audiovisual Media Services Directives, (accessed May 22, 2013), [available at http://ec.europa.eu/ avpolicy/reg/history/index_en.htm].

EASA ALLIANCE (2013). Web European Advertising Standards Alliance, (accessed May 24, 2013), [available at http://www.easa-alliance.org].

Foodnet (2013). Potravinářská komora, (accessed May 30, 2013), [available at http://zdravi.foodnet.cz/].

Garde, A. (2008). Food advertising and obesity prevention: What role for the European Union? Journal of Consumer Policy, 31(1): 25-44.

Grundey, D. (2007). Global Marketing Ethics: Social and Emotional-Psychological Issues in Advertising to Children. Transformations in Business and Economics, 6(2).

Hawkes, C. (2004). Marketing Food to Children: the Global Regulatory Environment. Geneva: World Health Organization.

IOTF. (2005). International Obesity Task Force, (accessed May 27, 2013) [available at http://www.iaso.org].

Leigh, J. H., Murphy, P. E. (1999). The role of formal policies and informal culture on ethical decision making by marketing managers, in Research in Marketing, ed. Sheth, J. N., Parvatiyar, A., 69-100.
McDonald's Cup (2013). McDonald's Cup, (accessed May 20, 2013), [available at http://www.mcdonaldscup.cz].

Potravinářská komora (2013). Potravinářská komora, (accessed May 30, 2013), [available at http://www.foodnet.cz].

Rada pro reklamu (2013). Rada pro reklamu, (accessed May 20, 2013), [available at http://www.rpr.cz].

Sbírka zákonů ČR (2013). Zákony - on-line, (accessed May 20, 2013), [available at http://zakony-online. $\mathrm{cz} /$ ?s171\&q171=all].

UN (2013). United Nations, (accessed May 30, 2013), [available at treaties.un.org/doc/source/training/regional/2009/13-17October-2009/human-rights.ppt].

World Health Organization (1998). The World Health Report 1998: Life in the 21st century. A vision for all, (accessed May 27, 2013), [available at www.who.int: http://www. who.int/whr/1998/en/whr98_en.pdf].

World Health Organization (2013). WHO: Obesity and overweight, (accessed May 27, 2013), [available at www.who. int: http://www.who.int/mediacentre/factsheets/fs311/en/ index.html].

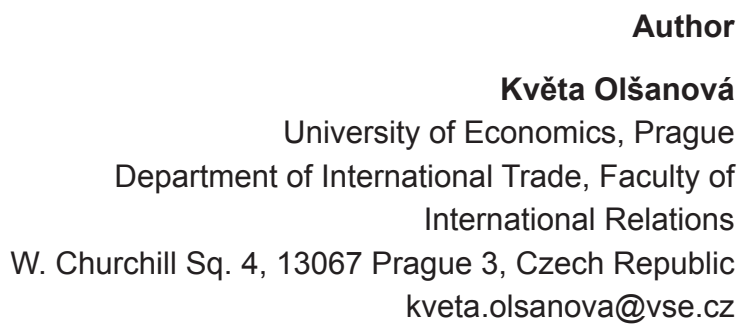

Author

Květa Olšanová

University of Economics, Prague

Department of International Trade, Faculty of International Relations

W. Churchill Sq. 4, 13067 Prague 3, Czech Republic kveta.olsanova@vse.cz

This article was prepared with support of the University of Economics' Internal Grant Agency under project number MF/13/2012 